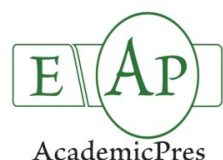

AcademicPres

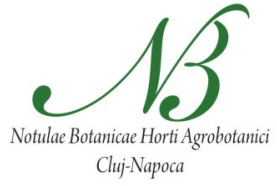

\title{
Parasitoids and Predators of Ips typographus (L.) in Unmanaged and Managed Spruce Forests in Natural Park Apuseni, Romania
}

\author{
Ciprian G. FORA ${ }^{1 *}$, Constantin M. BANU ${ }^{1}$, Ion CHISĂLIT, $\breve{A}^{1}$, \\ Mihaela M. MOATĂR ${ }^{1}$, Ion OLTEAN ${ }^{2}$ \\ ${ }^{1}$ University of Agricultural Sciences and Veterinary Medicine "Regele Mihai I al României" from Timişoara, Faculty of Horticulture and Forestry, Forestry \\ Department, 119 Calea Aradului 300645, Timişoara, Romania; foraciprian@yahoo.com ("corresponding author) \\ ${ }^{2}$ University of Agricultural Sciences and Veterinary Medicine Cluj-Napoca, Faculty of Agriculture, Plant Protection Department, 3-5 Mănăştur 400372, \\ Cluj-Napoca, Romania; ion.oltean@yahoo.com
}

\begin{abstract}
The last time span, of protected areas of forest ecosystems established raise of a variety of problems regarding frequency and intensity of the attack carried out by the rich pest complex affecting the trees' state of health. The current legislation forbids the application of pests control measures which can affect the biodiversity of these ecosystems. Species belonging to the useful entomofauna may interfere in the decrease of pest populations in these areas. The study of the parasitoid and predator complex has thus become a very topical research field, and these type of studies were carried out in Natural Park Apuseni, Romania. With the aim to identify present parasitoids and predators, 24 spruce $\operatorname{logs}$ provided from physiological weakened trees of $20-25 \mathrm{~cm}$ diameter and 1 $\mathrm{m}$ length were placed in 6 locations, in order to be populated by the spruce bark beetle Ips typographus (Linnaeus) as a trophic base of useful insect species. After its infestation the wood material was put in eclectors and analyzed weekly for the spruce bark beetle I $p s$ typographus, its parasitoids and predators. After examining collected biological material, 6 parasitoid species were identified which determined a $4.8 \%$ parasitization in unmanaged and $2.3 \%$ parasitization in managed forests. The best represented Hymenopteran parasitoids were Roptrocerus xylophagorum (Ratzeburg) and Rhopalicus tutela (Walker). The found Coleopteran predators were from 12 species, which belong to 4 families. The most captures were of the species Nemosoma elongatum (Linnaeus), representing 50.3\% of the total captured predators and Rhizophagus cribratus (Gyllenhaal), representing 9.5\% of the captures.
\end{abstract}

Keywords: insect natural enemies, parasitoids, predators, spruce bark beetle

\section{Introduction}

The spruce bark beetle, Ips typographus L., is considered to be one of the most destructive scolytid which attacks the spruce in Palaearctic regions (Christiansen and Bakke, 1988). One of the most harmful bark beetles is located in the spruce (Picea abies [L.] Karst.) forest stands in Romania (Oltean, 2003), as well as in another spruce species - Picea orientalis (L.) Link, Picea obovata Ledeb. and Picea jezoensis (Sieb. et Zucc.) Carr. (Simionescu, 1976). The population fluctuation depends on the presence of suitable brood material in the forest stands and on the good climatic conditions during the swarming (Escherich, 1942; Lobinger, 1994; Schwenke, 1974). In such situations the pest, which is usually capable to infest physiologically week, harmed trees (Lausch et al., 2011), is able to largely multiply and to turn to harmful to healthy standing trees (Arsenescu et al., 1966), thus becoming a primary pest. A series of factors, such as drought, soil water excess, tree crashes and cracks due to strong wind, wet snow, defoliation, heat strokes, fire, cryptogamic fungus, competition, age, pollution, predispose trees to spruce bark beetle attacks (Christiansen, 1991; Lausch et al., 2011; Faccoli and Bernardinelli, 2011, 2014).

Even though spruce bark beetle control strategies have been thoroughly studied in the course of time, the most efficient method to eradicate the pest outbreaks is to apply sanitation felling of infested trees, followed by the transportation of the infested wood outside the forest stands (Feicht, 2004). Anyway, if no immediate measures are taken to stop the spruce bark beetle outbreaks, the effects on the natural and planted forests are catastrophical on wide spread areas (Dengler, 1995; Niemeyer et al., 1995; Weslien and Schroeder, 1996). Zoophage species play a special role in the decrease of a pest population. Against this background, a special attention has been lately awarded to the spruce bark beetle parasitoids and predators. Remarkable research in this field was carried out by Krüger and Mills (1990), Hougardy and Grégoire (2001, 2004), Feicht (2004), Hilszczański et al. (2007), Marković and Stoianović (2010). This tendency is also justified by the fact that large conifer forest areas from Europe, including Romania in the last 15-20 years, have been included in the 
perimeters of protected areas. Such is the case of the Apuseni Mountains forests. Under these circumstances, various approaches in the national or natural park management occurred, in some perimeters, like those under strict or complete protection, numerous activities were forbidden, respectively allowed but with many restrictions, including that of pest control. These changes require management solutions in the case of the appearance of spruce bark beetle outbreaks, without affecting the environment, especially the biodiversity. In the Natural Park Apuseni the wooden vegetation is dominant and it covers approximately $75 \%$ of its total surface. The wooden species are mainly represented by spruce (70\%), beech (27\%), fir (2\%). Other conifer species, like the scots pine and the larch or deciduous trees like the ash, oak, sycamore maple, birch and the elm, can be found among the dominant species. The spruce form pure forest stands or mingle with the beech and the fir making up valuable forest stands.

In study areas the spruce bark beetle Ips typographus $\mathrm{L}$. have 2 flights on the growing season, spring flight in MaiJune and summer flight in July-August. Overwintering is mainly in adult stage, under the bark of infested spruce in summer.

In this study, we hypothesize that is difference of abundance of Ips typographus parasitoids and predators between unmanaged and managed spruce forests, it amid the fact that in managed forests a lot of branches and tops of trees remain in the forest after the cuttings and are populated by bark beetles. The aim of the study was to identify the parasitoid and predator species of the spruce bark beetle, Ips typographus L., and to determine their abundance in the spruce forests, unmanaged or managed, in the Natural Park Apuseni, in endemic conditions.

\section{Materials and methods}

For the identification of the useful entomofauna, in the Natural Park Apuseni, 6 spruce forest stand plots have been selected in the natural park, 3 in unmanaged forest stands from the areas Şesul Gârzii, Pârâul Ursului, Tomnatec and 3

Tab. 1. Experimental sites description in Natural Park Apuseni

\begin{tabular}{cccc}
\hline Plot name & $\begin{array}{c}\text { Elevation } \\
(\mathrm{m})\end{array}$ & $\begin{array}{c}\text { Type of } \\
\text { management }\end{array}$ & $\begin{array}{c}\text { Number of } \\
\text { sampled logs }\end{array}$ \\
\hline Şesul Gârzii & 1100 & Unmanaged & 4 \\
Pârâul Ursului & 1150 & Unmanaged & 4 \\
Tomnatec & 1150 & Unmanaged & 4 \\
Cheile Ordâncuşii & 1000 & Managed & 4 \\
Groapa de la Barsa & 1100 & Managed & 4 \\
Călineasa & 1150 & Managed & 4 \\
\hline
\end{tabular}

in managed forest stands from the areas Cheile Ordâncuşii, Groapa de la Barsa and Călineasa (Tab. 1).

The selection of experimental plots in 2012, for parasitoid and predator study, was made according to the I $I$ s typographus captures registered by the pheromone traps on the 24 surfaces placed in protected area and monitored in 2011, choosing the spruce forests where the largest captures occurred. Thus, before the start of the bark beetle flight, in April, in each plot, on 4 different places, spruce log samples have been placed in order to be populated by bark beetles. The logs have been taking from the same physiological weakened spruce tree. The logs were of $20-25 \mathrm{~cm}$ diameter and $1 \mathrm{~m}$ length. They were placed standing. At the middle of June the log samples have been introduced into the

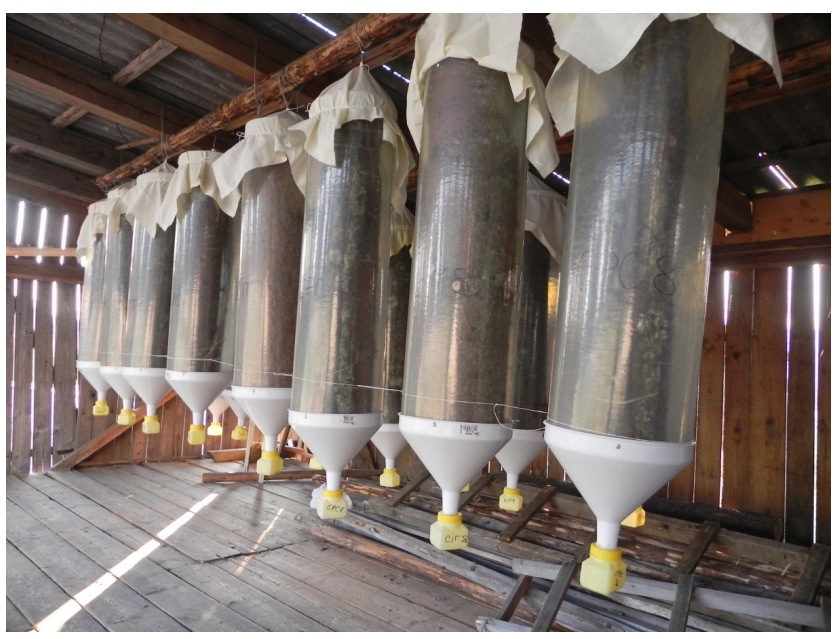

Fig. 1. Eclectors for insect captures

eclectors and hung on in the northern exposure buildings in the localities Casa de Piatră, Padiş and Doda Pilii (Fig. 1).

The thus made up eclectors were checked weekly until the middle of September. The insects harvested from each eclector were placed in plastic containers, numbered and dated. The samples were transported and analyzed in the Forest Entomology laboratory of the Faculty for Horticulture and Forestry Timişoara, with a view to determine insect species composition and their abundance. Also, the parasitoid percentage in unmanaged and managed forests was calculated following formula: hatched spruce bark beetles + hatched parasitoids $=$ potential beetles number; parasitism percentage $=$ parasitoids number $\times 100$ / potential beetles number.

The significance of differences between unmanaged and managed spruce forests, in Natural Park Apuseni, in the number of Ips typographus emerged beetles and in the number of its natural enemies was determined using oneway analysis of variance.

\section{Results and discussion}

The conducted studies in 2012 revealed that the 24 analyzed samples were parasitoids from 6 Hymenopteran species which, systematically, belong to two families Braconidae and Pteromalidae. The total number of collected specimens was of 375 individuals - 245 from unmanaged forests located in the preservation area $(65.33 \%$ of total captures), and 130 from managed forests located in the buffer park area (34.67\% of the total parasitoid captures). In the protected Apuseni perimeter, Roptrocerus xylophagorum Ratz. and Rhopalicus tutela Walk. were the most numerous and the most frequent occurred parasitoids of Ips typographus L.. The number of the collected 
272

parasitoids belonging to the species $R$. xylophagorum was 114 individuals, found in $92 \%$ of the eclectors from the preservation area, respectively in $83 \%$ of the eclectors from the buffer area. The other species - $R$. tutela was detected in $83 \%$ of the samples from the preservation area and $42 \%$ of the samples from the buffer area. The number of spotted individuals of this species was 111. Both species represent ectoparasitoids of the pest larvae. The parasitoids $R$. xylophagorum and $R$. tutela have frequently been encountered together on spruce trees attacked by $I p s$ typographus in unmanaged as well as managed forests, with a relatively uniform distribution on the monitored forest stands areas.

Another larval ectoparasitoid was Coeloides bostrichorum Gir. with a number of 76 individuals, signalled in $25 \%$ of the analyzed unmanaged forest samples, respectively $17 \%$ of the samples from managed forests. The collected individuals of the species Dendrosoter middendorff 2 Ratz. were 49, the species was detected in $33 \%$ of the preservation area eclectors, respectively in $58 \%$ of the samples from the buffer area. It was the only larval parasitoid signalled in several analyzed samples from the buffer area, but the number of individuls was larger than found in preservation area samples. In small numbers and with a low frequency Dinotiscus eupterus Walk. was encountered - in $17 \%$ of the preservation area samples and in $12 \%$ of the buffer area samples. The species C. bostrichorum was encountered grouped in the park perimeter, as well as Dinotiscus eupterus Walk. but in a smaller number. Tomicobia seitneri Rusch., ectoparasitoid of the imago, was encountered on a single location, in 3 individuals, only in the unmanaged forest.

The parasitization percentage determined for the Hymenopteran parasitoids ranged from $0.1 \%$ (T. seitneri) to $1.6 \%$ (R. xylophagorum) in unmanaged woods and from $0.1 \%$ (D. eupterus) to $0.8 \%$ ( $R$. tutela) in managed forests. The total parasitation by 6 parasitoid wasp species was $4.8 \%$ in unmanaged forests and $2.3 \%$ in managed forests. The results regarding the parasitoid species composition, their

Tab. 2. Parasitoid species of Ips typographus L., abundance and parasitization percentage in the Natural Park Apuseni

\begin{tabular}{|c|c|c|c|c|c|c|c|c|}
\hline \multirow{3}{*}{ Species } & \multicolumn{4}{|c|}{ Unmanaged forests } & \multicolumn{4}{|c|}{ Managed forests } \\
\hline & \multicolumn{2}{|c|}{ Eclector no. } & \multirow{2}{*}{$\begin{array}{l}\text { Parasitoids } \\
\quad \text { (no.) }\end{array}$} & \multirow{2}{*}{$\begin{array}{c}\text { Parasitation } \\
\text { (\%) }\end{array}$} & \multicolumn{2}{|c|}{ Eclector no. } & \multirow{2}{*}{$\begin{array}{l}\text { Parasitoids } \\
\quad \text { (no.) }\end{array}$} & \multirow{2}{*}{$\begin{array}{c}\text { Parasitation } \\
\text { (\%) }\end{array}$} \\
\hline & Total & $\begin{array}{c}\text { With } \\
\text { parasitoids }\end{array}$ & & & Total & $\begin{array}{c}\text { With } \\
\text { parasitoids }\end{array}$ & & \\
\hline \multicolumn{9}{|l|}{ Hymenoptera: Braconidae } \\
\hline Coeloides bostrichorum & 12 & 3 & 52 & 1.0 & 12 & 2 & 24 & 0.4 \\
\hline Dendrosotermiddendorffi & 12 & 4 & 26 & 0.5 & 12 & 6 & 23 & 0.4 \\
\hline \multicolumn{9}{|l|}{ Hymenoptera: Pteromalidae } \\
\hline Dinotiscus eupterus & 12 & 2 & 16 & 0.3 & 12 & 1 & 6 & 0.1 \\
\hline Rhopalicus tutela & 12 & 10 & 66 & 1.3 & 12 & 5 & 45 & 0.8 \\
\hline Roptrocerusxylophagorum & 12 & 11 & 82 & 1.6 & 12 & 10 & 32 & 0.6 \\
\hline Tomicobia seitneri & 12 & 1 & 3 & 0.1 & 12 & - & - & - \\
\hline Total & & & 245 & 4.8 & & & 130 & 2.3 \\
\hline
\end{tabular}

abundance and the parasitization percentage in the Natural Park Apuseni are presented in Tab. 2.

The special literature shows that the bark beetle parasitization percentage varies very much. The most parasitization percentages rarely exceed 10\%. Eck (1990) indicates a variation ranging from $0.1 \%$ to $70 \%$, Marcović and Stoianović (2010) - from 1\% to 15\%, Feicht (2006) from $1.2 \%$ to $92.2 \%$.

Gutowski and Krzysztofiak (2005) infer the fact that the strict reservations from the preservation area offer more favourable conditions for the development of parasitoids than the managed forests and this is the reason that Ips typographus parasitization to be larger in the unmanaged forests as compared to the managed ones. In our study no significant differences were found between unmanaged and managed spruce forests. The parasitoid abundance may be influenced by numerous factors, among which the bark beetle density, the predator density and the existence of alternative feed sources (Feicht, 2004).

The diagram of the parasitoid appearance in correlation with the host species was presented on the Figs. $2 a$ and $2 b$. As it could be noticed until the $23^{\text {rd }}$ of July the diagram of parasitoid appearance had a more accentuated rising than the diagram of Ips typographus. According to the experimental data, $72 \%$ of the parasitoids were observed until the moment of the maximum host flight. This fact could be explained by the fact that 5 of the found Hymenopterans are parasites of the last larvae stages and of the host pupae, thus confirming the tight correlation between natural enemies and their hosts, also claimed by Feicht (2004).

A total number of 10377 individuals of Ips typographus L. and 1581 predator individuals (798 in the preservation area samples and 783 in the buffer area samples) were collected (Tab. 3). The number of Ips typographus emerged from the single log are comparable in unmanaged and managed forest stands, no statistical differences were found, as previous studies have also reported (Faccoli, 2002). The predators belong to 12 species, 6 species are in Fig. $2 \mathrm{c}$ and additional 6 species, which were under 53 individuals each, in logs, was: Quedius cruentus Oliv., Quedius plagiatus Mannh., Nudobius lentus Grav., Oxypoda acuminata Steph., Tachinus elongatus Gyll., Epurea laeviuscula Gyll.. The predator/prey ratio was of 1:6.2 in unmanaged forests and of 1:6.9 in the managed forests area. A very small difference in species composition of predators could be observed between the two investigated areas contrariwise the parasitoids, which presented a higher abundance in the 
unmanaged areas as compared with the managed ones. All signalled predator species are from the Order Coleoptera and systematically belong to 4 families: Ostomidae, Monotomidae, Staphylinidae and Nitidulidae.

Regarding the abundance of signalled predators foremost the species Nemosoma elongatum L. was noticed with a number of 795 individuals, representing total up to $50.3 \%$ of the predators. The species was distributed uniformly in the studied area, being signalled in all analyzed eclectors. The next species, from the point of view of captures, was Rhizophagus cribratus Gyll. with 150 specimens (representing $9.5 \%$ of the predator total),

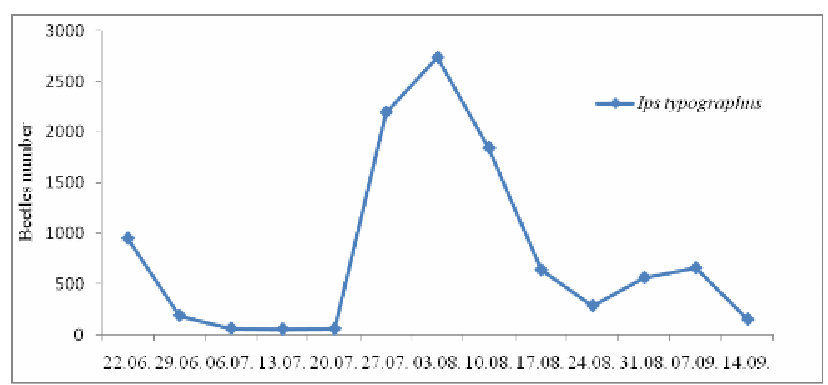

a)

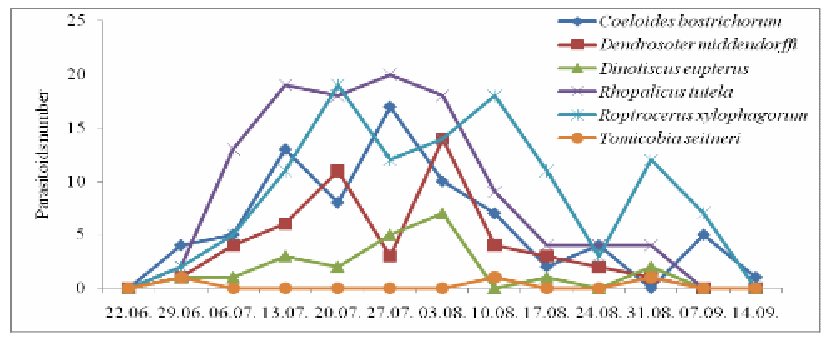

b)

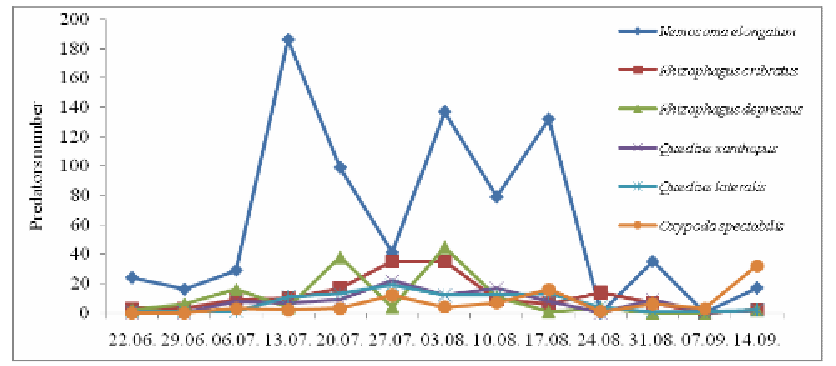

c)

Fig. 2. Total insects number from the analyzed spruce log samples: a) Ips typographus; b) parasitoids; c) predators

followed closely by $R$. depressus F. with 132 individuals (8.3\% of the predator total).

It was captured 289 individuals from the Genus Quedius (18.3\% of the total predator number) belonging to 4 species, and from the Genus Oxypoda 129 specimens ( $8.2 \%$ of the total predator number) belonging to 2 species. The least individuals were collected from the species $N$. lentus (25 specimens) and T. elongatus (20 specimens).

Regarding the predator appearance diagram it was observed a relative overlapping with the appearance of Ips typographus beetles. Predators consume the eggs and first larval stages of the host species. Thus, it was noticed that $67 \%$ of the predators were captured after the triggering of
Tab. 3. Species of Ips typographus L. predators, and their abundance in the Natural Park Apuseni

\begin{tabular}{|ccccc}
\hline & \multicolumn{2}{c}{ Unmanaged forests } & \multicolumn{2}{c}{ Managed forests } \\
\cline { 2 - 5 } Date & $\begin{array}{c}\text { Ips } \\
\text { typographus } \\
\text { no. }\end{array}$ & $\begin{array}{c}\text { Predators } \\
\text { no. }\end{array}$ & $\begin{array}{c}\text { Ips } \\
\text { typographus } \\
\text { no. }\end{array}$ & $\begin{array}{c}\text { Predators } \\
\text { no. }\end{array}$ \\
\hline 22.06. & 435 & 28 & 516 & 2 \\
\hline 29.06. & 101 & 3 & 87 & 24 \\
\hline 06.07. & 44 & 44 & 17 & 40 \\
\hline 13.07. & 38 & 58 & 15 & 177 \\
\hline 20.07. & 17 & 157 & 40 & 57 \\
\hline 27.07. & 1429 & 84 & 766 & 84 \\
\hline 03.08. & 1441 & 154 & 1295 & 131 \\
\hline 10.08. & 763 & 62 & 1080 & 101 \\
\hline 17.08. & 273 & 126 & 365 & 73 \\
\hline 24.08. & 70 & 20 & 215 & 13 \\
\hline 31.08. & 211 & 52 & 351 & 18 \\
\hline 07.09. & 90 & 0 & 568 & 8 \\
\hline 14.09. & 35 & 10 & 115 & 55 \\
\hline Total & 4947 & 798 & 5430 & 783 \\
\hline
\end{tabular}

the large spruce bark beetle flight and until the decrease in intensity of the flight (Figs. 2a and 2c).

Natural enemies probably play an important role in endemic situations and towards the end of an outbreak, understanding the interactions between bark beetles, antagonists, host plant and control measures will guide silvicultural practice to sustain to increase the regulatory capacities of natural enemies (Wermelinger, 2004).

Except the large spruce bark beetle another bark beetle species were found in the spruce samples collected from the monitored arboreta: Pityogenes chalcographus L., Ips amitinus Eichh., Ips acuminatus Gyll., Hylurgops glabratus Zett., Hylurgops palliatus Gyll. and Dryochoetes autographus Ratz.

\section{Conclusions}

In the conifer forest stands from the Natural Park Apuseni, Romania, numerous bark beetles outbreaks were registered, with the dominant species Ips typographus followed by $P$. chalcographus. The bark beetle parasitoid complex was represented especially by Hymenopteran parasitoids from the Braconidae and Pteromalidae families. In the studied area 6 parasitoid species were signalled. The most of the captured parasitoids (65.33\%) were from unmanaged forest samples versus $34.67 \%$ collected from managed forests. The parasitisation percentage of the species Ips typographus was of $4.8 \%$ in unmanaged forests from the park preservation area and of $2.3 \%$ in managed forests from the buffer area, the most significant parasitoid species considered to be $R$. xylophagorum and $R$. tutela. The predator complex was presented by 12 coleopteran species. The species $N$. elongatum and $R$. cribratus, followed by the species from the Genera Quedius and Oxypoda were encountered in the highest abundance. The predator/pray ratio was of 1:6.2 in unmanaged forests and of 1:6.9 in managed ones. In our study no significant differences were found between unmanaged and managed spruce forests by 
274

the point of view of Ips typographus emerged beetles, its parasitoids and predators.

\section{Acknowledgment}

This study was financed by the project "Postdoctoral School in Agriculture and Veterinary Medicine", POSDRU/89/1.5/S/6237, co-financed by the European Social Fund, through Sectorial Operational Programme for Human Resources Development 2007-2013. We thank to Prof. dr. dr.h.c. Karl Fritz Lauer (University of Applied Sciences Weihenstephan-Triesdorf/Freising), Mr. Adrian Mircu (Forest Research and Management Institute Timişoara) and to administration of Natural Park Apuseni for technical support and general permission.

\section{References}

Arsenescu M, Ceianu I, Fraţian Al, Iliescu Gh, Popescu T, Simionescu A (1966). Detection and prognosis of forest pests multiplying. Ed. Agro-Silvică, Bucharest, 180 p. (in Romanian).

Christiansen E (1991). Ips typographus and Ophiostoma polonicum versus Norway spruce: joint attack and host tree defence, p. 321334. In: Baranchikov YN, Mattson WJ, Hain FP, Payne TL (Eds.). Forest insect guilds: patterns of interactions with host trees US, For Serv, Northeast For Exp Stn, Gen Tech Rep NE-153.

Christiansen E, Bakke A (1988). The spruce bark beetle of Eurasia, p. 479-503. In: Dynamics of Forest Insect Populations. Patterns Causes, Implications. Berryman A. A. (Ed.), Plenum Press, New York.

Dengler K (1995). It is bark beetles control useful? Forst und Holz 50:244-249 (in German).

Gutowski JM, Krzysztofiak L (2005). Directions and intensity of migration of the spruce bark beetle and accompanying species at the border between strict reserves and managed forests in northeastern Poland. Ecol Questions 6:91-92.

Eck R (1990). The parasitic hymenopteran of Ips typographus in the phase of progradation. Species composition and parasitism in some forest areas of the former GDR. Entomologische Abhandlungen 53(11):152-178 (in German).

Escherich K (1942). The forest insects of Central Europe. Bd 5. Parey, Hamburg, 283 p. (in German).

Faccoli M (2002). Winter mortality in sub-corticolous populations of Ips typographus (Coleoptera, Scolytidae) and its parasitoids in the south-eastern Alps. Journal of Pest Science 75:62-68.

Faccoli M, Bernardinelli I (2011). Breeding performance of the second generation in some bivoltine populations of Ips typographus (Coleoptera, Curculionidae) in the South-Eastern Alps. Journal of Pest Science 84(1):15-23.

Faccoli M, Bernardinelli I (2014). Composition and elevation of spruce forests affect susceptibility to bark beetle attacks: Implications for forest management. Forests 5(1):88-102.

Feicht E (2004). Parasitoids of Ips typographus (Col., Scolytidae), their frequency and composition in uncontrolled and controlled infested spruce forest in Bavaria. Journal of Pest Science 77:165-172.

Feicht E (2006). Frequency, species composition and efficiency of Ips typographus (Col., Scolytidae) parasitoids in infested spruce forests in the national Park "Bavarian Forest" over three consecutive years. Journal of Pest Science 79:35-39.

Hilszczański J, Gibb H, Bystrowski C (2007). Insect natural enemies of Ips typographus (L.) (Coleoptera: Scolytinae) in managed and unmanaged stands of mixed lowlands forest in Poland. Journal of Pest Science 80:99-107.

Hougardy E, Grégoire JC (2001). Bark-beetle parasitoids population surveys following storm damage in spruce stands in the Vosges region (France). Int Pest Manag Rev 6:163-168.

Hougardy E, Grégoire JC (2004). Biological differences reflect host preference in two parasitoids attacking the bark beetle I $I$ s typographus (Coleoptera: Scolytidae) in Belgium. Bull Ent Res 94:341-347.

Krüger K, Mills N J (1990). Observations on the biology of three parasitoids of the spruce bark beetle, Ips typographus (Col., Scolytidae): Coeloides bostrychorum, Dendrosoter middenedorffi (Hym., Braconidae) and Rhopalicus tutela (Hym., Pteromalidae).J Appl Entomol 110:281-291.

Lausch A, Fahse L, Heurich M (2011). Factors affecting the spatio-temporal dispersion of Ips typographus (L.) in Bavarian Forest National Park: A long-term quantitative landscapelevel analysis. Forest Ecol Manag 261:233-245.

Lobinger G (1994). The air temperature as a limiting factor for the swarming of two spruce bark beetles, Ips typographus $\mathrm{L}$. and Pityogenes chalcographus L. (Col., Scolytidae). Anzeiger für Schädlingskunde, Pflanzenschutz, Umweltschutz 67(1):14-17 (in German).

Marcovic C, Stojanovic A (2010). Differences in bark beetle (Ips typographus and Pityogenes chalcographus) abundance in a strict spruce reserve and surrounding spruce forests in Serbia. Phytoparasitica 38:31-37.

Niemeyer H, Ackermann J, Watzek J (1995). An undisturbed mass reproduction of bark beetles (Ips typographus) in Hochhartz. Forst und Holz 50:239-243 (in German).

Oltean I (2003). Studies related to the bark pests dynamics in the forests of the Dorne area. J Central Europe Agric 4(3):251256.

Schwenke W (1974). The forest pests in Europe. Bd 2. Käfer. P. Parey Verlag, Hamburg-Berlin, 500 p. (in German).

Simionescu A (1976). Control of mainly spruce bark beetles. Ed. Ceres, Bucharest, 269 p. (in Romanian).

Wermelinger B (2004). Ecology and management of the spruce bark beetle Ips typographus - a review of recent research. Forest Ecol Manag 202:67-82.

Weslien J, Schroeder LM (1996). Natural dynamics of the bark beetle infestation after windthrow. AFZ für Waldwirtschaft und Umveltvorsorge 51(19):1052-1055 (in German). 